PETER RADAN, Professor of Law

Macquarie Law School, Macquarie University

Sydney, Australia
UDK 94(497.1)"1918/1941"

$342.2(497.1)^{\prime \prime} 1918 / 1941 "$

323.1(497.1)"1918/1941"

\title{
CONSTITUTIONAL EXPERIMENTATION AND THE NATIONAL QUESTION IN INTERWAR YUGOSLAVIA
}

\begin{abstract}
In 1993 the Hungarian-born historian John Lukacs wrote that the twentieth century was, by then, over. ${ }^{1}$ In his opinion it started with the outbreak of World War I in 1914 and ended with the collapse of the Union of Soviet Socialist Republics in 1989. Lukacs' 'short century' was also the period which saw the emergence and demise of Yugoslavia. The forces unleashed by the outbreak of World War I led to the birth of Yugoslavia in 1918. Similarly, the forces unleashed by the end of the Cold War contributed significantly to the wars that, from 1991 onwards, destroyed Yugoslavia. The historical forces that dominated the twentieth century - war or the threat of war and nationalism - also dominated Yugoslavia's history.
\end{abstract}

The Yugoslavia created in 1918 - officially known as the Kingdom of Serbs, Croats and Slovenes until 1929 - was a multi-national state with the Serbs, Croats and Slovenes its three constituent national groups. Yugoslavia's major problem was to find a means of attracting and maintaining the continued loyalty of its multi-national population. In trying to solve this 'national question' Yugoslavia's various political elites experimented with several structural administrative arrangements ranging from highly centralised-unitary to quasi-federal systems. Thus, attempts to resolve the national question focused on Yugoslavia's constitutional law and on whether Yugoslavia should have a centralised-unitary or decentralised-federal constitutional structure.

This article will detail the course of Yugoslavia's constitutional experimentation during the period between the two world wars of the twentieth century, that is, from Yugoslavia's formation in 1918 through to its temporary dismemberment at the hands of the Axis powers in 1941. The birth of Yugoslavia saw its political elites embark on what Alex Dragnich aptly labelled a 'Search for a Viable Political System'. ${ }^{2}$ The attempt to establish such a system during the interwar

${ }^{1} \mathrm{~J}$ Lukacs, The End of the Twentieth Century and the End of the Modern Age, Ticknor \& Fields, 1993.

${ }^{2}$ A N Dragnich, The First Yugoslavia, Search For a Viable Political System, Hoover Institution Press, 1983. 
period underwent four distinct phases, each involving a different approach. However, before these phases can be analysed, the formation of Yugoslavia and the political environment in which it arose must be first briefly detailed. This is because much of the debate that ensued during the interwar years was a consequence, not only of the absence at Yugoslavia's creation of any agreement as to its constitutional form and structure, but also the international setting in which this new multi-national state found itself at the time of its creation.

\section{8: The Creation of Yugoslavia}

The decisions leading to Yugoslavia's creation on 1 December 1918 were made by politicians. The question of unification was never directly put to the populations of the various territorial entities which constituted Yugoslavia. Some degree of popular support for unification could be seen in Montenegro where, on 26 November 1918, an elected National Assembly dethroned King Nikola I and the Petrović dynasty and voted for Montenegro's unification with Serbia under the Karađorđević dynasty. This assembly was elected in the month before the assembly vote was taken in an election in which the major issue was unification. The election of pro-unification delegates can be seen as evidence of popular support for unification. However, voters did not have details of the terms upon which unification was to take place. This was left to the elected assembly. The assembly revealed delegates opposed to the terms eventually adopted, even though these delegates were not opposed to unification in principle. ${ }^{3}$

The only direct popular vote concerning unification was in the Carinthia region on 10 October 1920. This plebiscite was a product of the Versailles Conference after World War I. The result of the vote was against unification with Yugoslavia and for incorporation into Austria. ${ }^{4}$ Carinthia had a two-thirds majority population of Slovenes, but only $41 \%$ of the population voted for unification with Yugoslavia. ${ }^{5}$ The voting patterns in Carinthia suggest that popular support for unification with Serbia was less than overwhelming amongst the Dual Monarchy's Slovenes. It is possible that similar sentiments were felt by the Croats of the former Dual Monarchy.

During all the political negotiations leading to the formation of Yugoslavia, there was no agreement reached as to the constitutional structure of the multi-national state. This fundamental question was left to be resolved once the state was formed. On this constitutional question the major point of contention was whether Yugoslavia should have a centralised-unitary or decentralised-federal

3 'Odluka Velike Narodne Skupštine Srpskog naroda u Crnoj Gori', 13. novembra 1918, in B Petranović \& M Zečević, Jugoslavija 1918-1984,'Rad', 1985, at 113-115.

${ }^{4}$ T M Barker, The Slovene Minority in Carinthia, East European Monographs, 1984, at 111-171.

${ }^{5}$ Barker, note 4, at $164-165$. 
constitutional structure. The major impulse for centralism came from the leaders of pre-World War I Serbia which was the largest and most politically powerful component of the new Yugoslav state. Federalism was championed by the new Croat political leaders that emerged once Yugoslavia was created. It was the struggle between these competing visions of the state that dominated the interwar period.

The other major national groups, the Slovenes and Slavic Muslims, did not feature prominently in the political struggle between the Serbs and Croats. The Slovenes, who largely supported the Slovene People's Party, were able to obtain a favourable arrangement with the central government in Belgrade. Possessed with a cohesive and compact political base and political and administrative skills, the Slovenes exploited Serbo-Croat tensions to achieve virtual self-administration for their region. The language difference between the Slovenes and the Serbs and Croats effectively prevented penetration of the local bureaucracy by non-Slovene elements. On the other hand the usually bi-lingual Slovenes could, and did, progress to the central government's bureaucracy. As a result the Slovenes were over-privileged both politically and administratively. ${ }^{6}$ The less numerous Slavic Muslims, located primarily in Bosnia, gathered around the Yugoslav Muslim Organisation, were generally prepared to trade their parliamentary weight for economic and cultural favours, and as such tended to be represented in most central governments of the interwar period. They too were politically overprivileged in the interwar period. ${ }^{7}$ Indeed it was Slavic Muslim support that enabled Serb parties to pass the centralist Constitution of $1921 .^{8}$

The aspirations of other national groups were either suppressed or of marginal interest to central state authorities. Into this category fell the Magyars of the Vojvodina region and the Albanians in Kosovo. The Macedonians were of some concern in that Macedonian separatism was advocated by the Internal Macedonian Revolutionary Organisation (IMRO) which was funded and supported by Bulgaria who saw the Macedonians as Bulgarians. However, the Macedonian problem was largely an international matter concerned with resisting Bulgarian irredentism.

The problems with the Macedonians points to a salient feature of Yugoslavia's efforts to resolve the Serbo-Croat conflict. Yugoslavia's internal political problems of this period occurred against an international background in which Hungary, Bulgaria and Italy harboured territorial ambitions which threatened Yugoslavia's territorial integrity. Although international borders between Yugoslavia and these states were determined by the mid-1920s, none of these Yugoslav neighbours abandoned irredentist claims against Yugoslavia. Yugoslavia's

\footnotetext{
${ }^{6} \mathrm{~J}$ Rothschild, East Central Europe Between the Two World Wars, University of Washington Press, 1974, at 208-209.

${ }^{7}$ N Malcolm, Bosnia, A Short History, Macmillan, 1994, at 172.

${ }^{8}$ L R Godtfredsen, Federalism and Yugoslav Political Integration, Unpublished Doctoral Dissertation, Tufts University, 1974, at 123.
} 
entry into the Little Entente and Balkan Pact was inspired by the need to protect its territorial integrity against its irredentist neighbours. The most significant external threat to Yugoslavia was posed by Italy under the leadership of Benito Mussolini. Mussolini's policy towards Yugoslavia aspired to gaining Yugoslav territory along the Adriatic coast which had been promised to Italy by the Treaty of London of 1915. ' Yugoslavia's internal conflict can only be properly understood with an appreciation of the impact of Yugoslavia's international position. The threat posed by Italy acted as a moderating influence on Croat demands in particular. The Croats sought a federal Yugoslavia, rather than seriously embracing separatist policies, because an independent Croat state would itself run the risk of being the victim of imperialist Italian ambitions.

\section{1-1929: The 1921 Constitution and the Period of Parliamentary Democracy}

The first phase of the effort to resolve the Serbo-Croat conflict was the period of parliamentary democracy which ended with the proclamation of King Aleksandar's personal rule in January 1929. In the period between the proclamation of Yugoslavia, on 1 December 1918, and the proclamation of the state's first constitution on 28 June 1921, Yugoslavia was governed and administered by seven appointed governments. Representatives to all of them came from the prewar states of Serbia and Montenegro and politicians from areas formerly under the Austro-Hungarian Empire. Serbia's pre-war state constitution was adapted to apply across the new Kingdom. A provisional legislature was also appointed, with its composition reflecting the major political parties and groupings from all territorial regions forming the new state. ${ }^{10}$ With the 28 November 1920 elections for a National Assembly to draft a new constitution, Serbo-Croat battle lines were drawn. The major Serb parties, the Radical Party led by Nikola Pašić and the Democratic Party led by Ljubomir Davidović, favoured a centralised state for Yugoslavia. ${ }^{11}$ The major Croat party, the Croat Peasant Party (CPP), led by Stje-

\footnotetext{
${ }^{9}$ E Milak, Italija i Jugoslavija 1931-1937, Beograd 1987, at 13-14, 19-31.

${ }^{10}$ On the provisional parliament see N Engelsfeld, Prvi parlament Kraljevstva Srba, $\mathrm{Hr}$ vata i Slovenaca, Globus, 1989.

${ }^{11}$ Not all Serbs favoured centralism. Given the multi-national composition of Yugoslavia, as compared to the nationally homogeneous Serbia of the nineteenth century, Pašić's deputy Stojan Protić argued, unsuccessfully, for a decentralised structure: Đ Stanković, 'Neuspeh Stojana Protića u okupljanju političkih snaga radi rešavanja hrvatskog pitanja 1921. godine' [1971] Istorijski glasnik, broj 2, 7-34; O Popović, Stojan Protić i ustavno rešenje nacionalnog pitanja u Kraljevini SHS, Savremena administracija, 1988. After the failure of centralism in the 1920s, the Democratic Party, by the end of the interwar period, moved to proposing a decentralised structure for Yugoslavia: 'Rezolucija glavnog odbora Demokratske stranke 1937', in B Petranović \& M Zečević, Jugoslovenski federalizam, Ideje i stvarnost, Prvi tom, 1914-1943, Prosveta, at 382-384; M Radojević, 'Demokratska stranka o državnom preuređenju Kraljevine Jugoslavije (1935-1941)' (1991) Istorija 20. veka, god. IX, broj 1-2, 37-62.
} 
pan Radić, boycotted the National Assembly and proceeded to draft a constitution for an independent state to be named the Neutral Peasant Republic of Croatia, which it justified on the basis of the Croat nation's right to self-determination. ${ }^{12}$ Other Croat parties favoured a federal approach to Yugoslavia's constitutional organisation..$^{13}$ The Radical-Democrat coalition, with support from a minor Slovene party (the Slovene Peasant Party), and Muslim parties from Bosnia and Hercegovina and southern Serbia and Macedonia (the Yugoslav Muslim Organisation and the South Muslim Organisation respectively), was able to secure the passage of the unitarist Constitution of the Kingdom of Serbs, Croats and Slovenes on 28 June $1921 .^{14}$

To the Serbs unitarism was the appropriate constitutional order. Pašić was a sincere believer in the merits of unitarism. He saw Serbia's problems historically as the result of internal weakness and bickering, dynastic rivalries and a weak central government. In discussions predating the formation of Yugoslavia he stated:

[W] ithout any single army, a single foreign policy, a united educational system there cannot be a strong state... [W]ithout a single legislature, a strong state cannot exist... and if we allow local law-making, we weaken the state as a whole and invite conflicts. ${ }^{15}$

To Pašic the rise of Serbian independence during the nineteenth century and Serbia's success in the Balkan Wars and World War I substantiated his viewpoint.

Radić's demands were for a loose federation of Serb, Croat, Slovene and Bulgarian regional units, in which regional governments possessed all powers except for specifically numerated and defined powers, such as national security and defence, which would belong to a central government. ${ }^{16}$ The demarcation of powers had a heavy bias in favour of regional autonomy and was very close to a form of confederation. ${ }^{17}$ Like Pašić, Radić was sincere in his political beliefs, and he too could rely on historical tradition. For many centuries Croatia had a special place within the Austrian and later Austro-Hungarian empires. This was symbolised by the existence of a Croatian Sabor which gave the Croats some degree of autonomy. The 1921 Constitution made no provision for the continuation of the Sabor. Indeed the creation of the Kingdom in 1918 was claimed to be illegal as it had been achieved without the consent of the Sabor. ${ }^{18}$ To Radic this amounted to

${ }^{12}$ M Biondich, Stjepan Radić, The Croat Peasant Party, and the Politics of Mass Mobilization, 1904-1928, University of Toronto Press, 2000, at 174-176; I Mužić, Stjepan Radić u Kraljevini Srba, Hrvata i Slovenaca, 4th Edition, Nakladni zavod Matice hrvatske, 1990, at 73-76.

${ }^{13}$ The various proposals for the Kingdom's constitutional structure are outlined in S Jovanović, Ustavno Pravo Kraljevine Srba, Hrvata i Slovenaca, Službeni list SRJ, 1995, at 65-85.

${ }^{14}$ Službene novine Kraljevine Srba, Hrvata i Slovenaca, broj 142a, 28. jun 1921.

${ }^{15}$ Quoted in Godtfredsen, note 8, at 89.

${ }^{16}$ Biondich, note 12 , at $161-164$.

${ }^{17}$ Godtfredsen, note 8, 116-117.

${ }^{18}$ Biondich, note 12, at 161; Cesarich claims that the National Council that voted for unification with Serbia and Montenegro was illegal because it was not a creation of Croatian constitu- 
a deprivation for Croatia of historic rights and meant that Croats were worse off within Yugoslavia than they had been within the Austro-Hungarian Empire. It is thus not surprising that up to the mid-1920s Radić at times called for the secession of Croatia from Yugoslavia. ${ }^{19}$

The unitarism of the 1921 Constitution was a reflection of the official view that the Serbs, Croats and Slovenes were three tribes of one unified nation, namely the Yugoslavs. During World War I, and after the Serbian government had officially adopted the creation of a unified Yugoslav state as its primary war aim, Pašić had consistently spoken of the Serbs, Croats and Slovenes as Yugoslavs, clearly implying that they were of the same ethno-cultural group. ${ }^{20} \mathrm{~A}$ similar approach was taken by the Yugoslav Committee. ${ }^{21}$ This approach was reflected in the provision, common to both the 1921 and 1931 constitutions, which stipulated that the official language of the state was 'Serbo-Croato-Slovenian' (Article 3 in both constitutions). ${ }^{22}$

Legislative power was shared between the King and National Assembly (Article 46). The National Assembly was a single chamber composed of members elected directly from single member electorates (Article 69). A government, appointed by the King (Article 90), did not even have to be drawn from members of the Assembly. ${ }^{23}$ Thus, even if a federalist opposition gained a majority in the Assembly, there was no constitutional requirement that a government had to come from within their ranks. Local self-government was through the system of 33 oblasti (districts). The oblast was the basic political, economic and administrative unit in Yugoslavia (Article 95).

The commitment of the Serb and Croat parties to their respective positions was disastrous for Yugoslavia's experiment with parliamentary democracy. The four national elections of the period revealed that within each ethnic community the strongest, most cohesive and reputedly most nativist party gained at the expense of the smaller, looser, and more ecumenical ones... Opposition to the re-

tional law: G W Cesarich, 'Yugoslavia was Created against the Will of the Croatian People' in A F Bonifačić \& C S Mihanovich (eds), The Croatian Nation in its Struggle for Freedom and Independence, 'Croatia' Cultural Publishing Center, 1955, 192-211, at 209.

${ }^{19}$ S Trifković, 'The First Yugoslavia and Origins of Croatian Separatism' (1992) 26 East European Quarterly 345-370, at 355-356; Biondich, note 12, at 183-184, 198.

${ }_{20}$ A N Dragnich, Serbia, Nikola Pašić, and Yugoslavia, Rutgers University Press, 1974, at 129-132. The view that Serbs, Croats and Slovenes formed one national group was largely based upon linguistic considerations and at the time was propagated in a number of influential publications such as L Dominian, The Frontiers of Language and Nationality in Europe, American Geographical Society, 1917, at 174-191; J Cvijić, 'The Geographical Distribution of the Balkan Peoples' (1918) 5 Geographical Review 345-361, at 355-361.

21 'Iz memoara Jugoslovenskog Odbora predanog francuskoj vladi u Parizu 6 maja 1915' in V Novak (ed), Antologija jugoslovenske misli i narodnog jedinstva (1390-1930), izdanje autora, 1930, at 715-716, referring to Serbs, Croats and Slovenes as 'one and the same people'.

22 Jovanović, note 13 , at $90-91$.

${ }^{23}$ Godtfredsen, note 8, at 121-122. 
gime ... expressed itself more vividly in ethnic than in social cleavages and solidarities. $^{24}$

By the late 1920s the tensions created by the Serb-Croat dispute were heightened to the point where parliamentary democracy was considered unworkable. A shooting incident in the National Assembly on 20 June 1928 indicated, and exacerbated, the political tensions of the time. On that day a Serb deputy shot and killed two Croat deputies. Radić was also wounded and later died on 8 August 1928. It became increasingly apparent that King Aleksandar would in some way intervene in an attempt to resolve the ongoing political instability. Aleksandar was not disposed towards a federalist solution. He was reported to have contemplated the 'amputation' of Croatia from Yugoslavia. ${ }^{25}$ On 6 January 1929, after consultations with major figures on both sides of the Serb-Croat political divide, Aleksandar abrogated the 1921 Constitution and instituted a period of personal rule. ${ }^{26}$

\section{9-1934: Aleksandar’s Personal Rule and Guided Democracy}

The second phase of the attempt to resolve the Serbo-Croat conflict was ushered in by Aleksandar's proclamation of 6 January 1929. In this proclamation he asserted that parliamentarism, instead of strengthening the unity of the state, was increasingly threatening it, and that it was therefore his duty to do all he could to preserve the unity of the state and its peoples. ${ }^{27}$ On the same day, by Royal

${ }^{24}$ Rothschild, note 6, at 219, 224.

${ }^{25}$ To what extent Aleksandar seriously contemplated 'amputation' is unclear. Such a solution was opposed by the Croat political leadership and apparently had only a minor level of support from Serb political leaders: R Horvat, Hrvatska na mučilištu, Školska knjiga, 1992, at 415417; Svetozar Pribičević, Diktatura kralja Aleksandra, Globus, 1990, at 67-69, 71-72; B Gligorijević, Kralj Aleksandar Karađorđević, Srpsko-hrvatski spor, Zavod za udžbenike i nastavna sredstva, 2002, at 315-321; Biondich, note 12, at 241-242; C A Nielsen, One State, One Nation, One King: The Dictatorship of King Aleksandar and His Yugoslav Project, 1929-1935, Unpublished Doctoral Dissertation, Columbia University, 2002, at 98-100. Nevertheless, just prior to his death Radić called for the secession of Croatia from Yugoslavia, and the formation of separate states joined together only by the fact that the monarch for both would be the same person: I Lukač, Stjepan Radić and the Croatian Peasant Party, 1914-1928, Unpublished Doctoral Dissertation, University of Cincinnati, 1989, at 172; Biondich, note 12, at 240.

${ }^{26}$ Aleksandar's action was initially, but only briefly, welcomed by Croat and Slovene leaders, in that they felt, in the words of Radić's successor as leader of CPP, Vladimir Maček, that 'the Croats will at last become masters of their own house in a free country': B E Bigelow, The Yugoslav Radical Union, A Failing Attempt at National Integration in Yugoslavia 1935-1941, Unpublished Doctoral Dissertation, University of Chicago, 1972, at 81-82.

27 'Proklamacija Kralja Aleksandra', 6. januara 1929, in Petranović \& Zečević, note 11, at 293-294. By the terms of the 1921 Constitution (Article 58), the King's oath of office swore him to protect 'the unity of the people, the independence of the state and its territorial integrity'. Aleksandar, given that he abrogated the 1921 Constitution, did not justify his action on his oath of office, but rather, as he declared in his Proclamation, on his 'holy duty' as well as his responsibility to the people and history and his love of the fatherland and respect for the countless who had died for the ideal of the unity of the people and state of Yugoslavia. 
Decree, the King's personal rule was confirmed (Article 2) ${ }^{28}$ Aleksandar's personal rule formally came to an end, and was followed by a period of 'guided democracy, ${ }^{29}$ with the promulgation on 3 September 1931 of a unitarist Constitution of the Kingdom of Yugoslavia. ${ }^{30}$ This Constitution was handed down by the King without any involvement of the population or its representatives.

King Aleksandar saw Yugoslavia's problems as stemming from inefficient administration and the divisive politics of the old National Assembly, and it was to these areas that he focused his energies. ${ }^{31}$

Administrative reform was two-fold. First, there was a vigorous campaign to eliminate corruption, inefficiency and nepotism within the bureaucracy. Positive results were quickly achieved and there was general approval of this bureaucratic reform. ${ }^{32}$ Second, there was a radical restructuring of the state into nine banovine (provinces), to replace the old division of 33 oblasti. ${ }^{33}$ Theoretically the banovine were supposed to be responsive to both provincial needs and the principle of central government. Aleksandar argued that the banovine would preserve regional traditions while building national unity. ${ }^{34}$

Administrative reform was coupled with political reform. On 3 October 1929 the state was renamed the Kingdom of Yugoslavia. ${ }^{35}$ Although this change of name merely confirmed the common practice of referring to the state as 'Yugoslavia', it also signified an important shift from a state of three peoples to a unitary state. ${ }^{36}$ During Aleksandar's personal rule all legislative authority was vested in the King. Under the 1931 Constitution legislative competence was shared between the King and the National Representation, a bicameral parliament containing a Senate and a National Assembly (Article 26). Half the senators were to be appointed and the other half elected (Article 50). National Assembly members were to be elected (Article 54). Legislation could be proposed by a Minister acting with the King's approval, or any member of the National Representation provided it was supported by at least one fifth of other such members (Article 63). The approval of both chambers was required for the passage of all laws. If the two chambers did not agree on proposed legislation the fate of the legislation

${ }^{28}$ 'Zakon o Kraljevskoj vlasti i o Vrhovnoj državnoj upravi'. 6. januar 1929, in Petranović \& Zečević, note 11, at 295-297. Article 2 stipulated: 'The King is the bearer of all authority in the country. The King declares and promulgates all laws'.

${ }^{29}$ Dragnich, note 2, at 86.

${ }^{30}$ Službene novine Kraljevine Jugoslavije, br. 207/1931.

${ }^{31}$ Bigelow, note 26, at 67-69; B Bigelow, 'Centralization Versus Decentralization in Interwar Yugoslavia' (1974) 1 Southeastern Europe 157-172, at 159-163.

${ }_{32}$ Bigelow, note 26 , at $73-75$.

33 'Zakon o nazivu i podeli Kraljevine na upravna područja', Article 2, 3. oktobar 1929, in Petranović \& Zečević, note 11, at 303.

${ }^{34}$ Bigelow, note 26, at 70-71; Nielsen, note 25, at 171-179.

35 'Zakon o nazivu i podeli Kraljevine na upravna područja', Article 1, 3. oktobar 1929, in Petranović \& Zečević, note 11, at 303.

${ }^{36}$ Nielsen, note 25 , at 168 . 
was determined by the King (Article 64). Governments were to be appointed by the King with all Ministers required to swear their loyalty to the King (Article 77).

The 1931 Constitution maintained a unitary system. The system of banovine, established in 1929, was continued (Article 83). The banovine provided for a degree of decentralisation, and were referred to as self-governing units (Article 84). Each banovina was headed by a Ban appointed by the King as the representative of the state (Article 85). Each banovina had a Council composed of elected members (Article 88). Each Council elected a Banovina Committee that acted as its executive organ (Article 89). The banovine had to act within the scope of competence permitted by law (Article 90) and were subject to the supervision of the central government (Article 92).

Political reform also entailed the banning of all nationalist political parties, soon to be followed by the banning of all political parties. Any organisation based upon national interests, from the (Serbian) Radical Party to the Union of Croatian Singing Societies, was banned. The provisions of an electoral law of 10 September 1931 effectively precluded regional parties from contesting any election for the National Representation. Only a government backed pan-Yugoslav political union could hope to succeed in such elections as was confirmed with the three elections held during the 1930 s pursuant to the 1931 electoral law. ${ }^{37}$ Aleksandar also established a central bank to replace existing national banking institutions.

The essential aims of Aleksandar's reforms were first, to establish a more effective centralised political system, and second, to suppress all forms of nationalistic expression. This policy of integral Yugoslavism was doomed to failure. The suppression of nationalism met with bitter resistance. ${ }^{38}$ Neither the Serbs nor Croats identified with Yugoslavism. The policy only served to inspire the formation of more extreme nationalist organisations, such as the separatist Croat Usta$\check{s} a$ movement, led by Ante Pavelić. Until 1936 the Ustaša policy of separatism was also supported by the CPP and its new leader Vladko Maček, with the two organisations engaged in tactical, but private, collaboration which saw them 'as

${ }^{37}$ In order to get on the ballot for the National Assembly election a 'candidates list' had to be signed by 60 (in 1933 this was reduced to 30 ) voters in at least half of the administrative units distributed across at least six banovine. In addition each candidate had to have 200 voters sign in support of that candidature. Finally, the candidates and leader of a list were required to sign declarations that they would protect the integrity of the state, work for national unity, and not join religious, national or regional party-political organisations. In an election the most successful candidates list would receive at least two-thirds of the seats in the National Assembly. These requirements prevented any anti-government list being able to organise for the election held on 8 November 1931 . Although a 'united opposition' list was organised for the elections held on 5 May 1935 and 11 December 1938, the governments of the day in each of the three elections were assured of victory given that they were able to exploit the machinery of government and administration to their advantage: F Čulinović, Jugoslavija između dva rata, Vol II, Izdavački zavod Jugoslavenske akademije znanosti i umjetnosti, 1961, at 40-45, 83-89, 131-133; Dragnich, note 2, at 86-88, 101-102, 110-111.

\footnotetext{
${ }^{38}$ Nielsen, note 25 , at $431-442$.
} 
factions of a single coalition pursuing different strategies in order to achieve a similar goal - the creation of an independent Croatian state'. ${ }^{39}$

The banovina system failed to operate as envisaged. Banovina officials, realising that their futures depended upon satisfying the demands of central authorities, diverted their energies to dealing with Belgrade rather than addressing the desires and needs of their constituents. As a result the public saw in the system nothing more than a desire to eliminate the old territorial units and the traditions that they represented. ${ }^{40}$ Furthermore, Aleksandar's authoritarian rule was bitterly resented both by Serbs and Croats. Serbs resented the abrogation of political and civil liberties for which they had struggled during most of the nineteenth century. Croats interpreted Aleksandar's suppression of nationalism as a mask for Serb hegemonism and as a deliberate programme of national genocide. ${ }^{41}$ By late mid-1934 Aleksandar recognised the system had to change. ${ }^{42}$ However, whatever plans he had in mind came to nothing. In October 1934, while on a state visit to France, Aleksandar was assassinated by a member of IMRO in the pay of the Ustaše.

\section{5-1939: The Yugoslav Radical Union, 1935-1939}

As Petar, Aleksandar's eldest son and heir, was not of majority age, the royal prerogative passed to a Regency Council, headed and dominated by Aleksandar's cousin, Prince Pavle. Pavle's choice as Prime Minister, Milan Stojadinović, initiated the third phase during the interwar period to find a workable solution to Yugoslavia's national question. Stojadinović formed the Yugoslav Radical Union (YRU), a coalition of elements of the former Radical Party, the Yugoslav Muslim Organisation and the Slovene People's Party. With the aim of reconciling the separate traditions of the Yugoslav peoples into a coherent whole, the YRU proposed a dual-level government. Local self-government was to apply as far as possible, with local districts having primary responsibility over local administration, agriculture, finance and cultural life. However, local interests were not permitted to supersede the interests of the state as a whole. Cooperation between local and central government was essential to the working of dual-level government. In many areas it did succeed, but it ultimately failed because it did not come to grips with the forces of nationalism. Improved economic conditions did nothing to alleviate nationalist tensions. ${ }^{43}$ $55-79$, at 57.

39 J J Sadkovich, 'Terrorism in Croatia, 1929-1934' (1988) 22 East European Quarterly

${ }^{40}$ Bigelow, note 26 , at 71 .

${ }^{41}$ Trifković, note 19 , at 362 .

${ }^{42}$ B Farley, Aleksandar Karadjordjević and the Royal Dictatorship in Yugoslavia' in B J Fischer (ed), Balkan Strongmen, Dictators and Authoritarian Rulers of Southeast Europe, Hurst \& Company, 2007, 51-86, at 82-83.

${ }^{43}$ Bigelow, note 26, Bigelow, note 31, at 163-168. 
Stojadinović failed because he misunderstood and underestimated the strength of political, national and religious traditions. Relative economic prosperity could not buy Stojadinović the loyalty of the Yugoslav peoples. Most significantly, Stojadinović was unable to co-opt Maček and the CPP into the YRU. Maček was inflexible in his refusal to negotiate with Stojadinović in relation to an agreement to resolve the Yugoslavia's national question. ${ }^{44}$ Combined with Stojadinović's poor showing in the 1938 general election Prince Pavle felt compelled to replace him. ${ }^{45}$

\section{9-1941: The Sporazum}

With Stojadinović's fall, Prince Pavle assumed a more prominent role in state affairs and thereby initiated the fourth and final phase during the interwar period to find a solution to Yugoslavia's national question. He sought a Prime Minister who would serve as a partner in his effort to reach an accommodation with Maček. Dragiša Cvetković was his choice. In light of the rise of Nazi Germany and the increased threat of a European war in the late 1930s, Pavle and Cvetković saw a resolution of the Serb-Croat conflict as of paramount concern. ${ }^{46}$ Pavle was also under significant international pressure, especially from Great Britain and Italy, to resolve Yugoslavia's internal problems so as to preserve its territorial integrity and prevent Germany from exploiting internal divisions and possibly dismembering it as had occurred in Czechoslovakia in $1938 .{ }^{47}$ The possibility of Yugoslavia's dismemberment was also a motivating factor for Maček to negotiate an agreement with Pavle. Nevertheless, in secret negotiations with Italy, Maček explored the option of an Italian-backed Croat insurrection against Yugoslavia with a view to establishing an independent Croat state in union with Italy. A preliminary agreement to that effect was negotiated in March $1939,{ }^{48}$ but Maček baulked at pushing ahead with it, preferring to make every effort to reach an accommodation with Cvetković and Pavle. Fear of the impact of the outbreak of World War II convinced Maček of the need to compromise in his negotiations with Cvetković. ${ }^{49}$ This approach led to the Sporazum (Agreement) of 23 August 1939 negotiated between the central government and Maček as leader of the CPP. ${ }^{50}$

\footnotetext{
${ }^{44}$ Bigelow, note 26, at 419.

${ }^{45}$ S Trifković, 'Yugoslavia in Crisis: Europe and the Croat Question, 1939-41' (1993) 23 European History Review 529-561, at 536.

${ }^{46}$ Bigelow, note 26, at 423 .

${ }^{47}$ G F Vrbanić, The Failure to Save the First Yugoslavia: The Serbo-Croatian Sporazum of 1939, Ziral, 1991, at 67-68.

${ }^{48}$ The terms of this preliminary agreement are reproduced in Bigelow, note 26, at $420-421$.

${ }^{49}$ Bigelow, note 26, at 429-430.

${ }^{50}$ The text of the Sporazum is reproduced in Petranović \& Zečević, note 11, at 508-510.
} 
The overriding factor that produced the Sporazum was, especially on the part of Prince Pavle, the defence of the territorial integrity of Yugoslavia. This was reflected in the opening words of the Sporazum which declared that 'Yugoslavia is the best guarantee of the independence and progress of the Serbs, Croats and Slovenes'. Negotiations leading to the Sporazum during 1939 were difficult and protracted. ${ }^{51}$ Maček on a number of occasions threatened secession if no agreement was reached. ${ }^{52}$ A major stumbling block was the territorial extent of any newly created Croatian banovina. It was agreed that the existing Savska and Primorska banovine would be within the new Croatian banovina, but its extension into Bosnia and Hercegovina was bitterly disputed and opposed by both Serb and Bosnian Muslim politicians. ${ }^{53} \mathrm{~A}$ further problem was Maček's insistence that the negotiations be conducted with a view to a restructuring of Yugoslavia through the National Assembly. Maček eventually conceded this demand and agreed to a settlement being promulgated by royal decree pursuant to Article 116 of the 1931 Constitution. ${ }^{54}$ This provision authorised the Crown to rule by decree in certain emergency situations. The effect of the Sporazum was to amend Article 83 of the 1931 Constitution on banovina borders by means of an agreement between the head of the government and the leader of the dominant Croat political party. It is clear that Article 116 did not authorise constitutional reform. ${ }^{55}$

The Sporazum was seen as a provisional agreement pending a final and future reorganisation of Yugoslavia which would entrench the Croatian banovina (Paragraphs 1,6). This was a reflection of the external circumstances which necessitated a speedy Serb-Croat agreement. The precise extent of the Croatian $b a$ novina was to be determined when Yugoslavia was finally reorganised (Paragraph 2).

By its terms the Sporazum granted the Croatian banovina extensive legislative competence. Matters relating to agriculture, commerce, industry, forests and mines, public works, social welfare, health, education, physical culture, justice and internal administration were the province of a revived Croatian Sabor (Paragraphs 4-5). Executive authority in the banovina was entrusted to a Ban, who was appointed by the Crown and responsible to the Crown and the Sabor (Paragraph 5) ${ }^{56}$ All other matters remained within the jurisdiction of the central go-

${ }^{51}$ D M Mangham, 'Elusive Agreement': The Sporazum of 1939 and the Serb-Croat Dispute in the Context of the European Crisis, Unpublished Master of Arts Thesis, Rice University, 1992 , at $170-174$, at $61-90$.

${ }_{52}^{52}$ Mangham, note 52, at 62-63, 88; Vrbanić, note 47, at 70-71.

${ }^{53}$ Mangham, note 52, at 76-78, 81 .

${ }_{55}^{54}$ Mangham, note 52, at 87 .

${ }^{55}$ M Stefanovski, 'Pitanje pravne valjanosti Uredbe o Banovini Hrvatskoj' in D Denković \& J Trkulja (eds), Pravna i politička misao Mihaila Ilića, Pravni fakultet Univerziteta u Beogradu, 1995, 306-317.

${ }_{56}$ The scope of the Croatian banovina power was later further extended to include control over police: Stefanovski, note 55, at 306. 
vernment (Paragraph 4). Definitive regulation of legislative competencies was deferred until the final reorganisation of the state (Paragraph 6). The equality of Serbs, Croats and Slovenes within the Croatian banovina was recognised, as was the equality of major religious denominations (Paragraphs 2-3). The terms of the Sporazum were formally proclaimed by decree on 26 August $1939 .^{57}$ A further decree on the same date anticipated that the earlier decree 'could be extended to other banovinas by royal decrees' and that this could be accompanied by existing banovinas being joined together or by changing their territorial scope. ${ }^{58}$

The Sporazum provisions were thus, but the first step towards the complete federalisation of Yugoslavia. However, it was unclear just how many other new banovinas there would be and what their borders would be. It was suggested that a Serbian banovina be created in what was left of Yugoslavia's territory after taking into account the Croatian banovina and a Slovenian banovina that would be constituted by the former Dravska banovina. ${ }^{59}$ Such a proposal met with opposition on two major fronts. First, there was Maček's repeated demand that the new Croatian banovina should be expanded in territorial scope beyond that envisaged by the Sporazum. Second, there was the demand by the leadership of the Muslims of Bosnia and Hercegovina for a banovina of their own within the territorial scope of historic Bosnia and Hercegovina's pre-Yugoslavia borders. ${ }^{60}$ However, none of the further re-organisation of Yugoslavia as anticipated by the Sporazum was achieved before Yugoslavia was drawn into World War II.

The most significant aspect of the Sporazum was the rejection of the idea of a single Yugoslav people that was implicit in the 1921 and 1931 Constitutions and in Aleksandar's policy of integral Yugoslavism. The distinct national identity of the Croats was clearly recognised by the Sporazum. However, rather than resolving the Serbo-Croat conflict it only served to exacerbate it. It led, as noted above, to differences over the Croatian banovina's final borders and the extension of the new arrangements to the rest of Yugoslavia. It also exacerbated more extreme sentiment amongst both Serbs and Croats. Maček found himself losing ground in Croatia to the Ustaša movement which sought total independence from Yugoslavia. ${ }^{61}$ To the Ustaše the Sporazum was, at best, but a small step towards independence, whereas Maček saw the Sporazum as a first step towards Croatia's quest for self-determination within the framework of a single Yugoslav state. Maček no longer advocated secession, and with four other members of his party joined the government on the day after the Sporazum was formally promulgated. ${ }^{62}$ Serb nationalist

57 'Uredba o banovini Hrvatskoj' in Petranović \& Zečević, note 11, at 516-516.

58 'Uredba o proširenju propisa uredbe o banovini Hrvatskoj na ostale banovine' in Petranović \& Zečević, note 11 , at 516.

${ }^{59}$ D Djokić, Elusive Compromise, A History of Interwar Yugoslavia, Columbia University Press, 2007, at 230-234.

${ }^{60}$ Djokić, note 59, at 235 .

61 Trifković, note 45, at 546-547; Vrbanić, note 47, at 99-111.

${ }^{62}$ Trifković, note 45 , at 545 . 
sentiment grew in opposition to the Sporazum. Many Serbs felt that too much had been conceded to the Croats. ${ }^{63}$ The ultimate expression of Serb nationalism was the military coup of 27 March 1941 which toppled Prince Pavle and the Cvetković government and installed King Aleksandar's son Petar, still a minor, to the throne. The coup leaders proclaimed internal factors as being the root causes for the coup, rather than dissatisfaction with Pavle's foreign policy which had led to Yugoslavia's adherence to the Tripartite Pact on 25 March 1941. The issue of what inspired the coup has long been a matter of historical controversy. ${ }^{64}$ It is indisputable however, that the coup was essentially organised and supported by Serbs and reflected deep Serb nationalist sentiment. The direct consequence of the coup was the German-led Axis invasion of Yugoslavia, launched on 6 April 1941. The German invasion accentuated Croat dissatisfaction with the Sporazum. As Dana Mangham has observed, the lack of Croat resistance to the invading Germans and their evasion of the military call-up demonstrated 'complete [Croat] unwillingness to defend the agreement Maček had made on their behalf - or at least defend what it had become by the spring of 1941'.65 The Axis invasion quickly resulted in the dismemberment of Yugoslavia in midApril 1941. Yugoslavia was now drawn into World War II.

Peter Radan

\section{USTAVNI EKSPERIMENT I NACIONALNO PITANJE U MEĐURATNOJ JUGOSLAVIJI}

\section{Rezime}

Neuspeh Kraljevine Jugoslavije da razreši nacionalno pitanje tokom svog postojanja bilo je u mnogome plod činjenice da nije postojao dogovor o ustavnim osnovama $u$ vremenu njenog stvaranja kao mulutinacionalne zajednice. Ovo je stvorilo vakuum u kome nije bilo moguće ponuditi pogodnu viziju jugoslovenske ustavne strukture. Sve se odigravalo u atmosferi pojačanog nacionalnog sentimenta, u državi čija je sama egzistencija bila pod pretnjom rastućih tenzija u evropskom političkom poretku. Jugoslovenski ustavni eksperiment nije razrešio nacionalno pitanje, niti je sačuvao Jugoslaviju od oluja koje je doneo Drugi svetski rat. Nasleđe međuratnih pokušaja da se reši nacionalno pitanje ostavilo je trag i na vojnim konfliktima na području Jugoslavije, koji su bili određujući za posleratno rešenje jugoslovenskog nacionalnog pitanja.

${ }^{63}$ For a detailed analysis of the various Serb responses to the Sporazum see Bigelow, note 26, at 436-471; Vrbanić, note 47, at 116-117; Djokić, note 59, at 238-246.

${ }^{64}$ Bigelow, note 26, at 472-474. The leaders of the coup believed that Yugoslavia's adhesion to the Tripartite Pact would encourage Croat separatism and generally opposed the provisions of the Sporazum on the ground that it weakened the centralist state: Mangham, note 52, at 125126. Croats saw the coup as a reaction to Prince Pavle and Cvetković yielding too much to the Croats: V Maček, In the Struggle for Freedom, Pennsylvania State University Press, 1957, at 220; Mangham, note 52, at 127-128; Vrbanić, note 47, at 123-133.

${ }^{65}$ Mangham, note 52, at 139. 